\title{
PERBANDINGAN EFEKTIVITAS PASTA GIGI HERBAL DENGAN PASTA GIGI NON HERBAL TERHADAP PENURUNAN INDEKS PLAK GIGI
}

\author{
${ }^{1}$ Edward S. Oroh \\ ${ }^{2}$ Jimmy Posangi \\ ${ }^{3}$ Vonny N. S. Wowor \\ ${ }^{1}$ Kandidat Skripsi Program Studi Pendidikan Dokter Gigi Fakultas Kedokteran \\ ${ }^{2}$ Bagian Farmakologi dan Terapi Fakultas Kedokteran \\ ${ }^{3}$ Program Studi Pendidikan Dokter Gigi Fakultas Kedokteran \\ Universitas Sam Ratulangi Manado \\ Email: edwardstevano@yahoo.com
}

\begin{abstract}
Plaque control is an attempt to remove and prevent the plaque accumulation on the tooth surface. Brushing teeth is an effective method in controlling plaque. Plaque control is equipped by additional active ingredients in toothpaste form. The addition of herbal ingredients in toothpaste expected to inhibit the growth of plaque because it as the ability to inhibit the growth of microbes. This study aimed to compare the effectiveness of herbal toothpaste and non herbal toothpaste in reducing plaque index. This was a quasy experimental study using a pretest-postest group design. Thirty subjects were taken by simple random sampling method and divided into 2 groups. Fifteen subjects of first group used herbal toothpastes and 15 subjects of the second group used non herbal toothpaste. This study held on one day only. Plaque indices were recorded according to Loe and Sillness plaque index. Paired t-test was used to compare the effectiveness of herbal toothpaste and non herbal toothpaste in reducing plaque index. The result showed that there was statistically significant difference reductions of plaque index before and after intervention of both group. Paired t-test statistical test showed $\mathrm{p}=0,000(\mathrm{p}<0,05)$ that indicated there were statistically significant difference beetwen plaque index of brushing with herbal toothpaste and non herbal toothpaste. Conclusion: There was differences in effectiveness between herbal toothpaste and non herbal toothpaste in reducing plaque index. Herbal toothpaste was more effective to reduce plaque index. Keywords: herbal toothpaste, non herbal toothpaste, plaque index
\end{abstract}

\begin{abstract}
Abstrak: Pengendalian plak merupakan upaya membuang dan mencegah penumpukan plak pada permukaan gigi. Menyikat gigi merupakan metode yang efektif dalam mengendalikan plak gigi. Penambahan kandungan herbal pada pasta gigi diharapkan dapat menghambat pertumbuhan plak karena memiliki kemampuan menghambat pertumbuhan mikroba. Penelitian ini bertujuan untuk mengetahui perbandingan efektivitas pasta gigi herbal dengan pasta gigi non herbal terhadap penurunan indeks plak. Penelitian ini merupakan penelitian quasy experimental dengan rancangan pre test post test group. Tiga puluh sampel diambil dengan metode simple random sampling dan dibagi dalam dua kelompok. Lima belas sampel pada kelompok pertama menggunakan pasta gigi herbal dan 15 sampel pada kelompok kedua menggunakan pasta gigi non herbal. Penelitian ini dilaksanakan hanya dalam satu hari. Indeks plak diukur berdasarkan indeks plak Loe and Sillness. Uji t berpasangan digunakan untuk membandingkan perbandingan efektivitas pasta gigi herbal dengan yang non herbal terhadap penurunan indeks plak gigi. Hasil penelitian menunjukkan terdapat perbedaan yang signifikan penurunan indeks plak gigi sebelum dan sesudah intervensi pada kedua kelompok. Uji t berpasangan menunjukkan $\mathrm{p}=0,000(\mathrm{p}<0,05)$ yang berarti terdapat perbedaan bermakna antara penggunan pasta gigi herbal dan pasta gigi non herbal terhadap penurunan indeks plak gigi. Pasta gigi herbal lebih efektif menurunkan indeks plak dibandingkan pasta gigi non herbal.
\end{abstract}

Kata kunci: pasta gigi herbal, pasta gigi non herbal, indeks plak gigi 
Kesehatan gigi dan mulut merupakan bagian dari kesehatan tubuh secara keseluruhan dan tidak dapat dipisahkan dari kesehatan tubuh secara umum. Kesehatan gigi dan mulut dapat memengaruhi kualitas hidup, oleh karena terganggunya fungsi bicara, pengunyahan dan estetik. ${ }^{1}$

Di Indonesia kesehatan gigi dan mulut merupakan hal yang perlu mendapat perhatian serius dari pemerintah dan tenaga kesehatan gigi. Hal ini disebabkan karena tingginya angka kejadian masalah gigi dan mulut di Indonesia, yakni sekitar 90\% penduduk menderita penyakit gigi dan mulut. Berdasarkan Riset Kesehatan Dasar (RISKESDAS) pada tahun 2013, masalah gigi dan mulut khususnya di Provinsi Sulawesi Utara sebesar 31,6\%. ${ }^{1-3}$

Masalah kesehatan gigi dan mulut yang terjadi umumnya disebabkan oleh plak gigi. Plak gigi merupakan suatu lapisan lunak yang terdiri atas kumpulan mikroorganisme dan berkembang biak dalam suatu matriks. Plak gigi melekat erat pada permukaan gigi yang tidak dibersihkan dan gusi serta permukaan keras lainnya dalam rongga mulut. Pada awal pembentukan plak gigi, kokus gram positif merupakan jenis mikroorganisme yang paling banyak dijumpai, seperti Streptococcus mutans, Streptococcus sanguis dan Streptococcus salivarius. Mikroorganisme tersebut memiliki enzim glucosyltransferase yang dapat memetabolisme karbohidrat menjadi asam sehingga menyebabkan karies, serta terjadinya penyakit periodontal akibat akumulasi plak gigi karena kebersihan mulut yang buruk. ${ }^{1,4}$

Pengendalian plak dapat dilakukan dengan cara pembersihan plak secara mekanis dan secara kimia dengan bahan anti kuman terutama untuk menekan pertumbuhan bakteri Streptococcus mutans. Secara mekanis, menyikat gigi membantu kontrol plak dan merupakan langkah awal untuk mengontrol karies serta penyakit periodontal baik untuk individu maupun populasi. ${ }^{4}$

Cara menyikat gigi dengan teknik dan metode yang benar beserta penggunaan pasta gigi sangat efektif untuk menjaga kebersihan gigi dan mulut. Menyikat gigi menggunakan pasta gigi dianjurkan dua kali sehari, yaitu sesudah makan dan sebelum tidur. Jenis pasta gigi yang digunakan merupakan salah satu faktor yang berperan di dalamnya, karena pasta gigi berfungsi untuk mengurangi pembentukan plak, memperkuat gigi terhadap karies, membersihkan dan memoles permukaan gigi, menghilangkan atau mengurangi bau mulut, memberikan rasa segar pada mulut serta memelihara kesehatan gingiva. ${ }^{4,5}$

Saat ini, telah dikembangkan pasta gigi herbal sesuai dengan meningkatnya minat masyarakat terhadap penggunaan bahan alami. Pasta gigi herbal mengandung sodium bikarbonat, sodium florida dan kandungan bahan herbal. Bahan herbal yang dipakai memiliki sifat anti inflamasi yang diketahui mampu menstimulasi respons imun, memiliki sifat anti perdarahan, sebagai bahan antiseptik alami, dan memiliki sifat antiseptik, dan analgesik. $^{5,6}$

Terdapat beberapa penelitian yang menunjukkan efektivitas pasta gigi herbal dan non herbal dalam mengatasi plak. Dinyatakan bahwa pasta gigi herbal mampu mengatasi plak lebih baik dibandingkan pasta gigi non herbal, tetapi pada penelitian lainnya menunjukkan pasta gigi herbal memiliki efektivitas yang setara dengan pasta gigi non herbal dalam menurunkan indeks plak. ${ }^{6}$

Hasil penelitian yang bervariasi dari beberapa penelitian tersebut mendorong penulis untuk melakukan penelitian tentang perbandingan efektivitas pasta gigi herbal dengan non herbal terhadap penurunan plak. Penulis memilih mahasiswa Program Studi Pendidikan Dokter Gigi Universitas Sam Ratulangi (PSPDG Unsrat) Angkatan 2012 sebagai populasi yang diteliti karena populasi ini lebih mudah dijangkau dari segi tempat, waktu, dan biaya, sehingga memudahkan penelitian.

\section{METODE PENELITIAN}

Penelitian ini merupakan penelitian quasy eksperimental dengan rancangan pre 
test post test group design. Penelitian ini dilaksanakan bulan Maret sampai September 2015 di PSPDG UNSRAT. Populasi penelitian ini yaitu seluruh mahasiswa preklinik angkatan 2011 PSPDG UNSRAT yang berjumlah 105 mahasiswa. Besar sampel yang digunakan pada penelitian ini sebanyak 30 sampel yang mengacu pada besaran sampel minimal yang dapat digunakan dalam penelitian eksperimental sederhana, dengan metode simple random sampling.

Pasta gigi herbal, yaitu pasta gigi yang dominan memiliki kandungan bahan herbal yang terdiri dari ekstrak jeruk nipis dan daun sirih. Pasta gigi herbal yang digunakan yaitu pasta gigi herbal dengan merek dagang pepsodent herbal. Pasta gigi non herbal yang digunakan yaitu pasta gigi dengan bahan aktif fluoride, dengan merek dagang pepsodent.

Indeks plak, yaitu indeks plak menurut Loe and Sillness, berupa angka yang menunjukkan luasnya plak yang menutupi permukaan gigi indeks.

Cara pengukuran yaitu: Jumlah gigi yang diperiksa yaitu enam gigi yaitu gigi $12,16,24,32,36,44$. Permukaan gigi yang diperiksa ada empat, yaitu bukal atau labial, lingual atau palatal, mesial dan distal. Semua kelompok dilakukan pengukuran skor plak menurut Loe dan Sillness dengan pemberian disclosing solution dan dicocokkan dengan tabel scoring plak gigi seperti yang tercantum di bawah ini:

Skor 0: Tidak ada plak

Skor 1: Selapis tipis plak yang hanya dapat dilihat dengan bantuan sonde atau disclosing solution

Skor 2: Lapisan plak dengan akumulasi sedang, yang dapat dilihat dengan mata telanjang

Skor 3: Plak dengan akumulasi banyak dari bahan lunak yang mengisi celah antar tepi gingiva dan permukaan gigi

Penilaian indeks plak gigi diperoleh dengan cara menjumlahkan skor indeks plak per satu gigi dibagi jumlah gigi yang diperiksa. Setiap area yang terdapat plak diberi skor berkisar 0 sampai 3. Untuk pemberian kategori skor indeks plak menurut Loe dan Sillness, yaitu untuk kategori sangat baik diberi nilai 0 , kategori baik diberi nilai 0,1-0,9, untuk kategori sedang diberi nilai 1,0-1,9, dan untuk kategori buruk dengan nilai 2,0-3,0.

$\begin{array}{ll}\text { Indeks plak }= & \begin{array}{l}\text { Jumlah skor plak pada } \\ \text { permukaan gigi yang diperiksa }\end{array} \\ \begin{array}{l}\text { Jumlah permukaan gigi yang } \\ \text { diperiksa }\end{array} \\ \text { Indeks plak }= & \begin{array}{l}\text { Jumlah skor plak pada seluruh } \\ \text { permukaan gigi yang diperiksa }\end{array} \\ \text { Jumlah gigi yang diperiksa }\end{array}$

\section{HASIL PENELITIAN DAN BAHASAN}

Pemeriksaan meliputi indeks plak gigi pada penggunaan pasta gigi herbal dan pasta gigi non herbal berdasarkan jenis kelamin dan usia yang dapat dilihat dari diagram dan tabel 1-5. Pada penelitian ini karakteristik jenis kelamin subjek penelitian perempuan sedikit lebih banyak daripada laki-laki sebesar 53\%. Karakteristik usia terbanyak pada usia 21 tahun sebesar $50 \%$.

Tabel 1. Distribusi karakeristik subjek penelitian berdasarkan jenis kelamin

\begin{tabular}{ccccc}
\hline & \multicolumn{2}{c}{ Perempuan } & \multicolumn{2}{c}{ Laki-laki } \\
\cline { 2 - 5 } & $\mathrm{n}$ & $\%$ & $\mathrm{n}$ & $\%$ \\
\hline $\begin{array}{c}\text { Pasta gigi } \\
\text { herbal }\end{array}$ & 7 & 23 & 8 & 27 \\
$\begin{array}{c}\text { Pasta gigi non } \\
\text { herbal } \\
\text { Total }\end{array}$ & 9 & 30 & 6 & 20 \\
\hline
\end{tabular}

Tabel 2. Distribusi karakeristik subjek penelitian berdasarkan usia

\begin{tabular}{ccc}
\hline $\begin{array}{c}\text { Usia } \\
\text { (tahun) }\end{array}$ & $\mathrm{n}$ & $\%$ \\
\hline 19 & 1 & 3 \\
20 & 12 & 40 \\
21 & 15 & 50 \\
22 & 2 & 7 \\
Total & 30 & 100 \\
\hline
\end{tabular}


Tabel 3. Distribusi indeks plak pada responden yang menggunakan pasta gigi herbal

\begin{tabular}{ccccc}
\hline \multirow{2}{*}{ Indeks Plak } & \multicolumn{4}{c}{ Pasta Gigi Herbal } \\
\cline { 2 - 5 } Gigi & \multicolumn{2}{c}{ Sebelum } & \multicolumn{2}{c}{ Sesudah } \\
\cline { 2 - 5 } & $\mathrm{n}$ & $\%$ & $\mathrm{n}$ & $\%$ \\
\hline Sangat baik & - & - & - & - \\
Baik & - & - & 11 & 73 \\
Sedang & 7 & 47 & 4 & 27 \\
Buruk & 8 & 53 & - & - \\
Total & 15 & 100 & 15 & 100 \\
\hline
\end{tabular}

Tabel 4. Penilaian efektivitas pasta gigi herbal dan non herbal berdasarkan penurunan indeks plak

\begin{tabular}{ccccc}
\hline & \multicolumn{4}{c}{ Nilai Rerata } \\
\cline { 2 - 5 } $\begin{array}{c}\text { Pasta } \\
\text { gigi }\end{array}$ & $\begin{array}{c}\text { Indeks } \\
\text { plak } \\
\text { sebelum }\end{array}$ & $\begin{array}{c}\text { Indeks } \\
\text { plak } \\
\text { sesudah }\end{array}$ & $\begin{array}{c}\text { Penuruna } \\
\mathrm{n}\end{array}$ & $\%$ \\
\hline Herbal & 2,08 & 0,48 & 1,60 & 76,9 \\
Non & 2,09 & 1,06 & 1,03 & 49,3 \\
herbal & & & & \\
\hline
\end{tabular}

Hasil penelitian dalam Tabel 5 menunjukkan tidak terdapat indeks plak dengan kategori baik dan sangat baik pada pengukuran indeks plak gigi sebelum penggunaan pasta gigi herbal.

Tabel 5. Uji statistik perbandingan efektivitas pasta gigi herbal dengan pasta non herbal terhadap penurunan indeks plak gigi

\begin{tabular}{lcc}
\hline Indeks plak gigi & \multicolumn{2}{c}{ Mean } \\
\cline { 2 - 3 } & $\begin{array}{c}\text { Penggunaan } \\
\text { pasta gigi } \\
\text { herbal }\end{array}$ & $\begin{array}{c}\text { Penggunaan } \\
\text { pasta gigi } \\
\text { non herbal }\end{array}$ \\
\hline $\begin{array}{l}\text { Sebelum diberi } \\
\text { perlakuan }\end{array}$ & 2,08 & 2,09 \\
$\begin{array}{l}\text { Sesudah diberi } \\
\text { perlakuan }\end{array}$ & 0,48 & 1,06 \\
$P$ value & \multicolumn{2}{c}{0,003} \\
\hline
\end{tabular}

Penilaian indeks plak berada pada kategori sedang dan buruk, dimana hasilnya hampir berimbang namun yang lebih banyak berada pada kategori buruk. Setelah perlakuan, diperoleh hasil penilaian indeks plak berada pada kategori sedang dan baik. Hasil yang sama diperoleh pada pengukuran indeks plak pada penyikatan gigi menggunakan pasta gigi non herbal. Hasil ini didukung oleh penelitian yang dilakukan Cahyanti tahun 2014 pada siswa kelas VIII SMPK 1 Harapan Denpasar dan penelitian Hebal tahun 2012 di Belgaum yang menunjukkan bahwa terdapat perbedaan yang signifikan antara sebelum dan setelah penggunaan pasta gigi herbal maupun pasta gigi non herbal. ${ }^{7,8}$

Menurut pendapat penulis, adanya perubahan dari hasil penilaian indeks plak sebelum dan sesudah penggunaan pasta gigi herbal dan non herbal antara lain disebabkan oleh efek dari tindakan penyikatan gigi. Tekanan bulu sikat yang dihasilkan lewat tindakan menyikat menyebabkan sisa makanan dan plak pada permukaan gigi hilang atau berkurang. Penelitian yang dilakukan oleh Kharisma tahun 2013 mengenai perbedaan efektivitas sikat gigi elektrik dengan sikat gigi manual terhadap penurunan indeks plak pada anak tunagrahita di SDLB Putra Jaya Malang menyatakan bahwa plak gigi tidak dapat dihilangkan dengan cara kumur ataupun semprotan air, tetapi hanya dapat dibersihkan dengan cara mekanis yaitu menyikat gigi karean tindakan penyikatan gigi dapat menyingkirkan plak dan debris makanan. ${ }^{9}$

Perubahan hasil penilaian indeks plak gigi juga disebabkan karena dalam kedua pasta gigi tersebut terdapat bahan abrasif yang mampu meningkatkan daya abrasif sikat gigi sehingga lebih memudahkan pembersihan dan pemolesan gigi tanpa merusak email. Pasta gigi juga mengandung bahan pembersih yang berfungsi menurunkan tegangan permukaan dan melonggarkan ikatan debris dengan gigi yang akan membantu gerakkan pembersihan sikat gigi. Kandungan bahan abrasif dan detergent menyebabkan pembuangan plak, debris, material alba, dan sisa makan menjadi lebih muda. Kondisi inilah menurut penulis yang memengaruhi penurunan indeks plak. ${ }^{7,10}$

Penilaian indeks plak gigi dengan kategori baik lebih banyak pada penggunaan pasta gigi herbal dibandingkan pada penggunaan pasta gigi non herbal, 
yakni sebesar 73\% pada pasta gigi herbal dan 33\% pada pasta gigi non herbal. Tabel 7 menunjukkan indeks plak gigi pada penggunaan pasta gigi herbal mengalami penurunan sebesar 76,9\%, sedangkan penurunan indeks plak gigi pada penggunaan pasta gigi non herbal sebesar 49,3\%. Hasil penilaian indeks plak gigi selain dipengaruhi oleh tindakan penyikatan gigi, juga dipengaruhi oleh kelebihan daya antibakteri dalam kandungan minyak atsiri pada daun sirih dan jeruk nipis dalam pasta gigi herbal. ${ }^{7}$

Minyak atsiri daun sirih dan jeruk nipis memiliki aktivitas antibakteri terhadap streptococcus mutans lebih besar dari fluor. Minyak atsiri mempunyai fungsi sebagai antibakteri terhadap beberapa bakteri yaitu Staphylococcus aureus, Bacillus cureus, Salmonella typi, dan golongan Candida albicans. Daya antibakteri minyak atsiri disebabkan oleh adanya senyawa fenol dan turunannya yang dapat mendenaturasi protein sel bakteri. Penelitian Pratiwi tahun 2011 mengenai gambaran efek pasta gigi yang mengandung herbal terhadap penurunan indeks plak menyatakan bahwa pasta gigi herbal daun sirih mampu menurunkan indeks plak gigi. Jeruk nipis dapat menghambat pembentukan plak dengan cara menghambat pembentukan pelikel, pertumbuhan koloni bakteri dan meningkatkan kecepatan saliva dan penurunan viskositas saliva. Penelitian yang dilakukan oleh Fitarosana tahun 2012 di Semarang menunjukkan hasil terjadi penurunan indeks plak gigi pada pemberian larutan jeruk nipis $65 \%$. ${ }^{71-13}$

Uji normalitas Shapiro-Wilk menunjukkan seluruh data terdistribusi secara normal. Berdasarkan uji parametrik t-test berpasangan, hasil analisis perbandingan efektivitas pasta gigi herbal dengan pasta non herbal terhadap penurunan indeks plak gigi pada penelitian ini didapatkan nilai 0,003 ( $\mathrm{p}<0,05$ ). Hal ini menunjukkan bahwa terdapat perbedaan efektivitas yang signifikan antara pasta gigi herbal dan non herbal terhadap penurunan indeks plak gigi. Pada kelompok perlakuan yang menyikat gigi dengan pasta gigi herbal menghasilkan penurunan akumulasi plak yang lebih besar dari kelompok yang menyikat gigi dengan pasta gigi non herbal. Terjadinya penurunan akumulasi plak yang lebih besar pada penggunaan pasta gigi herbal dibandingkan dengan pasta gigi non herbal disebabkan karena kelebihan kandungan minyak atsiri pada daun sirih dan jeruk nipis dalam pasta gigi herbal tersebut.

Penelitian ini didukung dengan penelitian yang dilakukan Rahma tahun 2014 mengenai perbandingan efektivitas pasta gigi herbal dengan pasta gigi non herbal terhadap penurunan indeks plak pada siswa SDN Angsau 4 Pelaihari. Hasil penelitiannya menunjukkan terdapat perbedaan bermakna yakni pasta gigi herbal lebih efektif menurunkan indeks plak dibandingkan pasta gigi non herbal. Hasil peneltian Cahyanti tahun 2014 juga mendukung penelitian ini. Pada hasil penelitiannya didapatkan nilai rata-rata penurunan akumulasi plak lebih besar pada kelompok pasta gigi herbal daun sirih dibandingkan pasta gigi non herbal fluoride. ${ }^{7,10,14}$

\section{SIMPULAN}

Terdapat penurunan indeks plak gigi yang bermakna antara sebelum dan setelah menyikat gigi dengan pasta gigi herbal dan pasta gigi non herbal. Indeks plak gigi pada penggunaan pasta gigi herbal mengalami penurunan sebesar 76,9\%, indeks plak gigi pada penggunaan pasta gigi non herbal mengalami penurunan sebesar 49,3\%. Pasta gigi herbal lebih efektif menurunkan indeks plak gigi dibandingkan yang non herbal.

\section{SARAN}

1. Diharapkan adanya penelitian lebih lanjut mengenai perbandingan efektivitas pasta gigi herbal dengan pasta gigi non herbal terhadap penurunan indeks plak gigi.

2. Bagi klinisi diharapkan agar dapat menyarankan dan memberi sosialisasi mengenai penggunaan pasta gigi herbal sebagai alternatif dalam menurunkan akumulasi plak, serta digunakan dalam merawat rongga mulut karena pasta gigi 
herbal berasal dari bahan alami sehingga aman digunakan.

3. Bagi masyarakat diharapkan agar menjaga kesehatan rongga mulut seperti rajin menyikat gigi dengan pasta gigi dan dianjurkan untuk menggunakan pasta gigi herbal terutama bagi yang beresiko tinggi memiliki tingkat kebersihan mulut buruk, kontrol ke dokter gigi setiap enam bulan sekali, melakukan pembersihan karang gigi, memakai obat kumur, membersihkan gigi setelah makan dengan dental floss.

\section{DAFTAR PUSTAKA}

1. Eliza H, Tati SI, Sri A. Pendidikan kesehatan Gigi. Jakarta: EGC, 2012; p. 118.

2. Erna G. Perbedaan pembersihan gigi menggunakan kayu siwak (Salvadora persica), sikat gigi dengan pasta gigi ekstrak siwak dan non herbal terhadap penurunan plak [Tesis]. Yogyakarta: FKG UMY; 2012.

3. Riset Kesehatan Dasar (RISKESDAS) 2013. Laporan Nasional. Kementerian Kesehatan Republik Indonesia; 2014. p.117

4. Inne SS, Arleta SPP, Musttaqin $H$. Gambaran efek pasta gigi yang mengandung herbal terhadap penurunan indeks plak. Bandung: FKG Unpad, 2013.

5. Citra LW, Benny MS, Fadli J. Effectiveness of herbal and non-herbal toothpastes in reducing dental plaque accumulation. Journal of Dentistry Indonesia. 2012;19(3):70-4.

6. Stefani AD, Fadli J, Benny S. Herbal and conventional toothpastes roles in gingivitis control in orthodontic patients. Journal of Dentistry Indonesia. 2011;18(3):68-72.

7. Putu IC. Penggunaan pasta gigi herbal daun sirih lebih menurunkan akumulasi plak gigi daripada pasta gigi non herbal pada siswa kelas VIII SMPK 1 Harapan Denpasar [Skripsi]. Denpasar: FKG Univeristas Mahasaraswati; 2014.

8. Hebbal M. Effectivness of herbal and fluorinated toothpaste on plaque and gingival scores among residents of a working women's hostel - a randomized controlled trial. Oral Health Prev Dent. 2012;10(4):389-95.

9. Kharisma AP. Perbedaan efektivitas sikat gigi elektrik dengan sikat gigi manual terhadap penurunan indeks plak pada anak tunagrahita di SDLB Putra Jaya Malang. Malang: Pustaka Universitas Brawijaya, 2013; p. 3.

10. Rahmah RY. Perbandingan pasta gigi herbal dengan pasta gigi non herbal terhadap penurunan indeks plak pada siswa SDN Angsau 4 Pelaihari. Dentino. 2014;II(2):120-4.

11. Rini DM, Mulyono. Khasiat dan manfaat daun sirih. Jakarta: Agromedia Pustaka, 2009; p. 4, 5, 10-2.

12. Pertiwi ASP. Gambaran efek pasta gigi yang mengandung herbat terhadap penurunan indeks plak [serial online]. Bandung: Pustaka Ilmiah Unpad, 2011. [cited July 2015]. Available from: http//pustaka.unpad.ac.id.

13. Sarwono B. Khasiat dan manfaat jeruk nipis. Jakarta: Agromedia Pustaka, 2009; p. 13-5.

14. Fitarosana EA. Pengaruh pemberian larutan ekstrak jeruk nipis terhadap pembentukan plak gigi [Skripsi]. Semarang: FK Undip; 2012. 